\title{
PHOTO ESSAY
}

\section{Remembering the Struggle for the Environment: Hamilton's Lax Lands/Bayfront Park, 1950s-2008 \\ Nancy B. Bouchier \& Ken Cruikshank.}

Historians of the environment often face the challenge of documenting natural or built features that may not be known to their readers, or, as importantly, that existed in forms radically different from their present form. Even those most familiar with a contemporary landscape may not recognize it in its historical form. The past really can be another country. Although environmental historians continue to rely on written observations, they cannot help but be attracted to visual images, particularly photographs and films. Why? Like social historians, environmental historians use photographs for the same reason and in the same ways that they use objects or oral interviews, as sources of information that have not been captured by another surviving document. Visual images are simply one source among many, although critics suggest that many historians are even more naive than usual about the 'objectivity' question, especially when it comes to photographs. "We rely on them," Joan Schwartz notes, "as surrogates for firsthand seeing, to extend the powers of human observation across space and across time."1

Critics are not kind to this common use of photographs. Art historian John Tagg saves his harshest words for "'social' or even 'socialist'...histories...that have seized on every picture of a factory or worker, every picture of or by a member of the working class, and have imagined them to constitute evidence of a 'hidden' history... What such accounts entirely erase is the multiplicity of social sites and social practices in which the representations they appropriate were produced and seen as meaningful." ${ }^{2}$ Schwartz is somewhat gentler, but nevertheless calls upon historians to be "more imaginative about the questions we pose," and encourages us to think about intention, meanings for different viewers at the time and later, and "what cannot be seen in a photograph." In their own work, Tagg and Schwartz are particularly adept at thinking about how photographs "participate in the processes by which... the world has been shaped and reshaped."’3

A photographic essay itself participates in these processes. For this very reason, we are quite willing to be more imaginative in the questions we pose, but we are not ready to abandon the notion that historical photographs extend the powers of human observation across time, or may constitute evidence of histories that would otherwise be hidden. We select, reproduce and order these photographs of Hamilton's Lax Lands/Bayfront Park into an essay quite deliberately to circulate and give meaning to images, some of which otherwise would remain

\section{(C) Left History}

13.1 (Spring/Summer 2008) 
stored away in filing cabinets or cardboard boxes. If these photographs constituted an argument when they were first produced, they are reproduced in this essay also to constitute an argument. We have selected them because of the work that they did in the past as a part of a debate about a place in a particular time. They also have been selected, we admit, because they represent one of the best ways to document the history of a place. We reproduce these images because, as in many places, the controversy over and struggle to create a place-in this case a waterfront park on infilled land in an industrial city-is hidden. We believe it is important for environmental historians to tell stories that show that important features of our urban landscapes - whether valued or not-were not, and therefore are not, inevitable. These photographs help convey one such story.

In this photographic essay we seek to remember the struggle that led to the creation of a public waterfront park along the southwestern shoreline of Hamilton Harbour. As historians, we see the controversy that led to the creation of this park as a key turning point in what one observer in the early 1970 s called "the battle to unchain Hamilton Bay" from a post-World War II trajectory of industrial and commercial development. ${ }^{4}$ The Hamilton Lax Lands controversy is an important part of the history of environmental activism and waterfront development since the 1960s, which parallels wider developments in the history of North American waterfronts and environmental activism.

\section{The Hamilton Harbour Commission at Work}

By 1957, the date of our first image, much of Hamilton Ontario's waterfront had been constructed, and continued to be under construction, in order to facilitate industrial and port development. We designed Figure 1, based on historical maps, to show how human intervention altered the original shoreline of Hamilton Harbour (a.k.a. Burlington Bay). In the 1850s, the Great Western Railway dumped material into the southwestern bay as they excavated and levelled the existing shoreline property, creating some 50 acres of land. In the final decades of the nineteenth century, Hamilton's municipal government began filling in the southeastern shore and inlets of the bay as a convenient way of dealing with nuisance lawsuits brought against the city by owners of waterfront property damaged by effluent flowing from city sewer pipes. ${ }^{5} \quad$ This also increased the amount of land available for industrial development in the area located between the bay and the Niagara Escarpment (a.k.a. 'Hamilton Mountain'). Created in 1912, Hamilton's Harbour Commission provided the city with an agency with the entrepreneurial energy and financial resources for getting the job of port and industrial development done. ${ }^{6}$ Like Toronto's Harbour Commission, the Hamilton Harbour Commission became heavily involved with land development, using fill from public works projects to increase waterfront land. 'While the changes to Hamilton's waterfront land occurred incrementally over many years - an inlet filled in here, a 
Figure 1. Turning Water into Land, 1909-1996

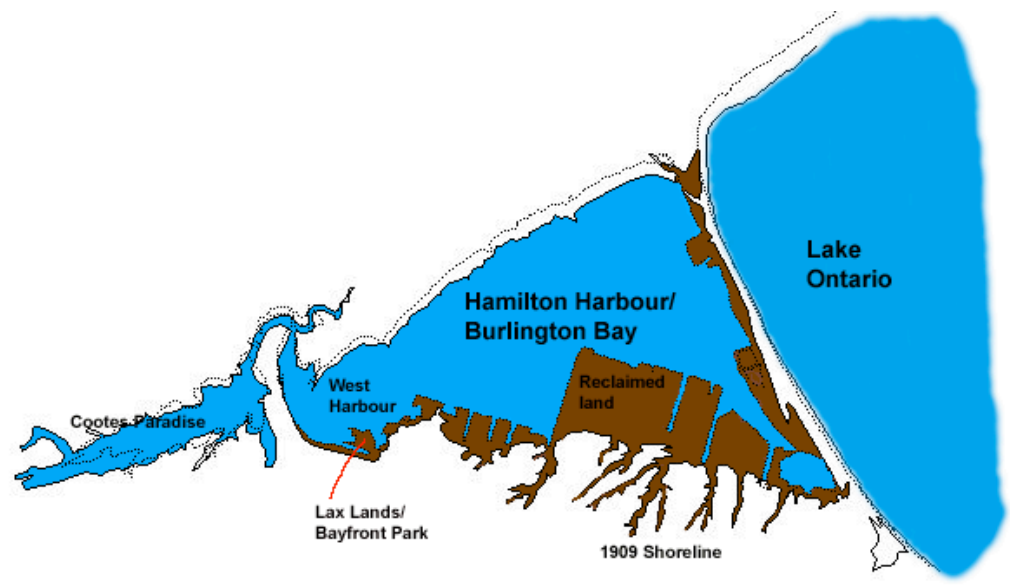

Based upon: Canada. Department of Militia and Defense. Topographic Map. Ontario Hamilton Sheet. 1:63,360 (Geographical Section, General Staff, No 2197, Sheet No. 33, 1909); Canada. Department of Energy, Mines and Resources. Canada Centre for Mapping. Hamilton Burlington Ontario. 1:50,000 (Canada. Sheet 30 M/5 Ed.9, 1996). Outline created by McMaster University Library Lloyd Reeds Map Collection, using ArcView 3.2, as a subset of the original dataset with csdtype = IRI (18 June 2001).

\section{Figure 2. Wasted Water Lots in the West Harbour, 1957}

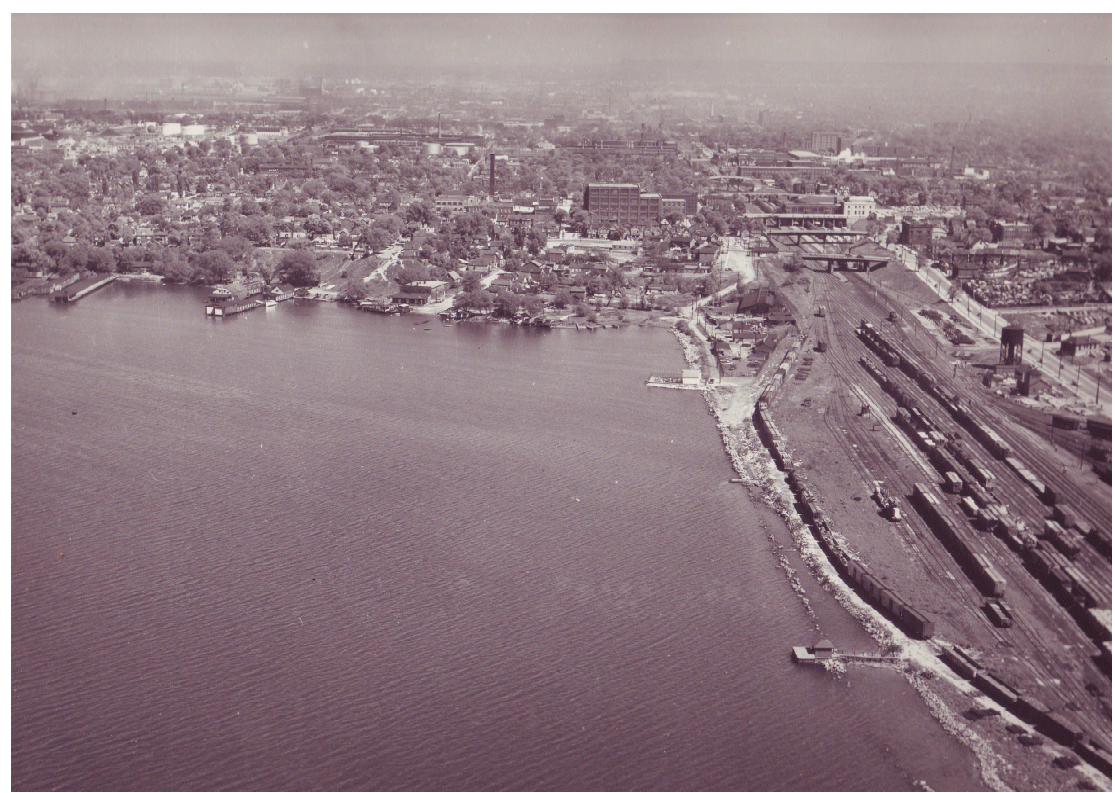

Courtesy of Hamilton Port Authority, photographer unknown. 
revetment wall hardening up the shoreline there-the pace of harbour infilling quickened through the twentieth century. By the 1970s, an estimated 30 percent of the water surface was "reclaimed" as land.

Without this context, and without our caption "Wasted Water Lots on the West Harbour", Figure 2 might represent a puzzling, oddly-composed photograph. Water-calm and featureless - dominates the image. Making sense of this photograph requires a contextual knowledge of sponsor, time, and place. This is wasted waterfront space. This is real estate for sale. The Harbour Commission's aerial photograph emphasizes the water as potential industrial and commercial site - the amount of space it represented and the location's advantages can be measured by the freight trains and rail yards to the right, and the rails that stretch through the city to the horizon. What few other details are visible tend to reinforce the value associated with the rail yards - a large factory appears to confirm the nature of the district yet small docks suggest an area whose potential has yet to be captured. About the only things missing from this photograph are the dotted lines drawn in with magic marker by some unknown planner that are found on some other Harbour Commission photos, lines outlining the water lots that could be purchased, filled in, and used for industrial or port facilities. ${ }^{8}$

The photograph was taken in 1957, just as the new St Lawrence Seaway was being completed, promising Hamilton ready access to ocean freighters and shipping networks across the Atlantic Ocean. The place recorded is the southwestern shore of the harbour, an area that, although the site of the city's original rail yards and factories, had been neglected by industrialists and the Harbour Commission in favour of areas to the east, closer to Lake Ontario. By 1957, photographs such as this one indicated that the Harbour Commission had begun to include the west harbour in its search to maximize future port traffic. ${ }^{9}$ One of its plans and maps envisioned this area reclaimed as land, with a bridge joining the north and south shores, creating a way to efficiently carry goods-laden trucks from western Hamilton to Toronto. Such a bridge was no more ambitious nor fanciful than the nearly-completed Burlington Skyway Bridge that dominated the eastern end of the harbour. ${ }^{10}$

The Harbour Commission's marketing of the west harbourfront water lots attracted a buyer. In 1959, a local and successful scrap metal firm, the Lax Brothers, acquired rights to some of the water lots and then gradually acquired adjacent shore lands. By the mid-1960s, the firm had enough property to begin planning for a 40 to 50 acre industrial park, much of it to be created by dumping fill into the relatively shallow water lots. ${ }^{11}$ Figure 3, also from the Harbour Commission, represents one of many shots that documented this process of land reclamation. Photographs such as this monitored and celebrated improvements made to the harbour. This 1973 photograph is more tightly focused than the one from 1957. It emphasizes the work that is being done, and what could be done with the remaining unsold water lots. It also emphasizes the rail yards and facto- 


\section{Figure 3. Making Water Lots Productive}

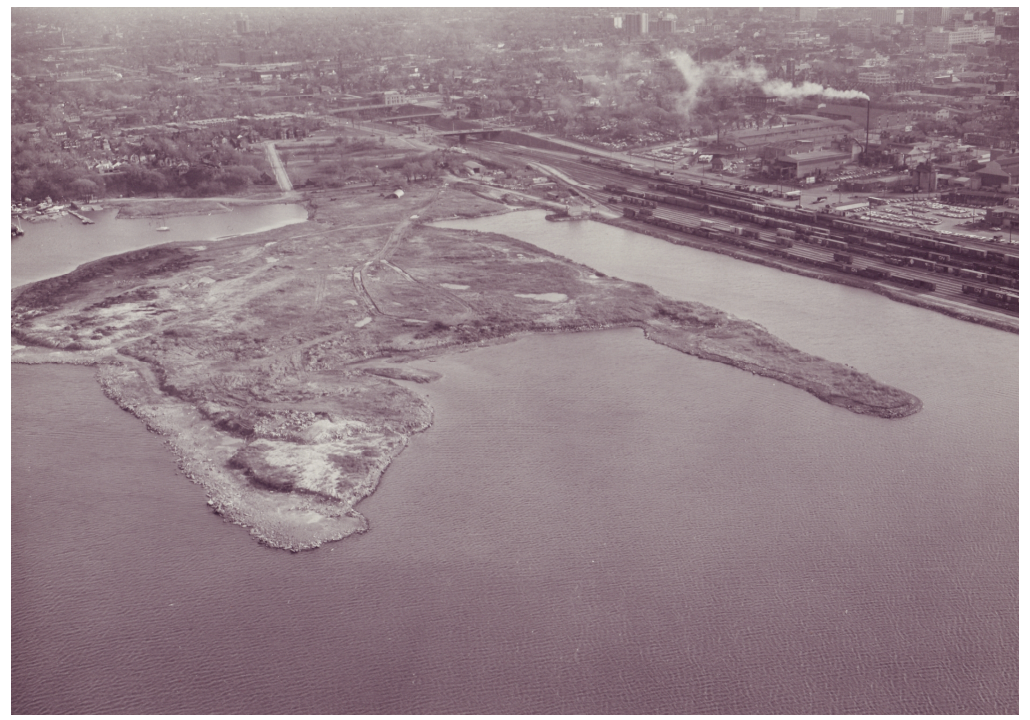

November 1973 (5539-5). Courtesy of Hamilton Port Authority, Photographer: Phil Aggus and Son Ltd. Hamilton.

ries in the area, but the angle has changed since the factory that appeared in the 1957 background had closed and had been replaced by housing in the 1960s. Interestingly, this Harbour Commission photograph focuses on industry and transportation, even though in the 1960s the Lax Brothers abandoned their industrial plans and proposed designs first for Bal Harbour and later Bayshore Village, both grand complexes to house some 15,000 people. ${ }^{12}$ The plans for these communities boasted accompanying green space and private marinas on reclaimed land.

Reclamation was nothing new in the 1970s when the photograph shown in Figure 4 was taken, but this photograph celebrates the new technologies that made intensified filling possible. This Harbour Commission photo is unusually intimate; it captures a truck stuck on the thin projection of dumped fill and a bulldozer which is perhaps coming to its aid. It captures both the challenge and achievement of large infilling projects, and it is framed in such a way as to suggest that what is seen is just a momentary setback in port development-something easily fixed. The background of the photo delivers a powerful message of progress that is about the success of Hamilton's industrial waterfront. The viewer's gaze is drawn past the isolated vehicles, across the water to the steel mills, where smokestacks, cranes, and a Canada Steamships Line carrier show that business is flourishing. This busy port was built out of nothing-upon land reclaimed from the bay's eastern inlets, just as the infilling in the foreground would in time provide space for more docks, wharves and warehouses. Although perhaps diffi- 


\section{Figure 4. Celebrating Technology}

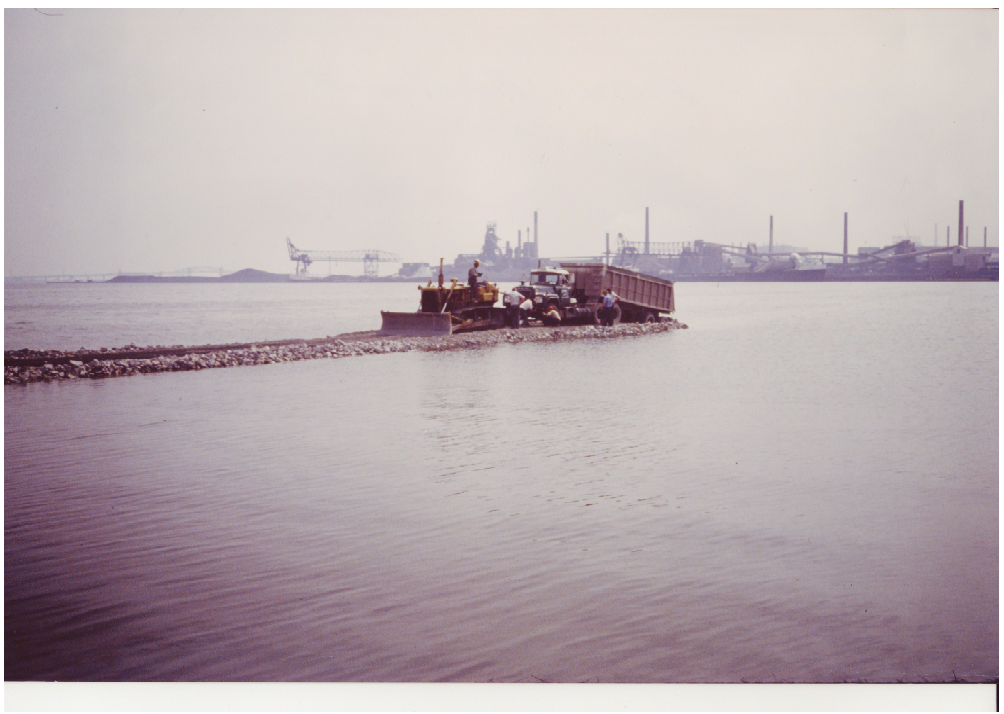

Infilling Pier 12-3 stage 1a, 1978. Courtesy of Hamilton Port Authority, Photographer unknown.

cult to see in some reproductions, the photograph also captures the Burlington Skyway bridge portion of the Queen Elizabeth Way, passing over the strip of land known as the beach strip, which separated the bay from Lake Ontario.

For historians, Figures 3 and 4 have added layers of meaning. By 1978, when photograph 4 was taken, the official plans for the harbour had stalled, mired in controversy. By then, infilling and other harbour improvements had been extremely restricted for nearly eight years. ${ }^{13}$ Figure 3 can be read as a symbol of resistance to the Commission's environmental imaginary, for in it the infilling had ceased. By 1978, only a few older projects, including the one pictured in Figure 4, were restarting. As one federal government official explained to his political master, "Without going into any details...suffice it to say that overwhelming constraints of an environmental, urban land use and jurisdictional nature have effectively prevented any but the most elementary housekeeping works to be entertained." ${ }^{14}$ Those "constraints" are the subject of our next photographs.

\section{Activists at Work}

In their introduction to Locating Memory: Photographic Acts, Annette Kuhn and Kirsten Emiko McAllister note the proliferation of photographic images of people and places from other times, and the "...potential for radical politics with, for example, tactics for recognizing the fragmented, contradictory stories and the excluded voices amidst the plenitude; stories and voices that demand that we 
Figure 5. Ti Estin-Moving Earth: A Critical View

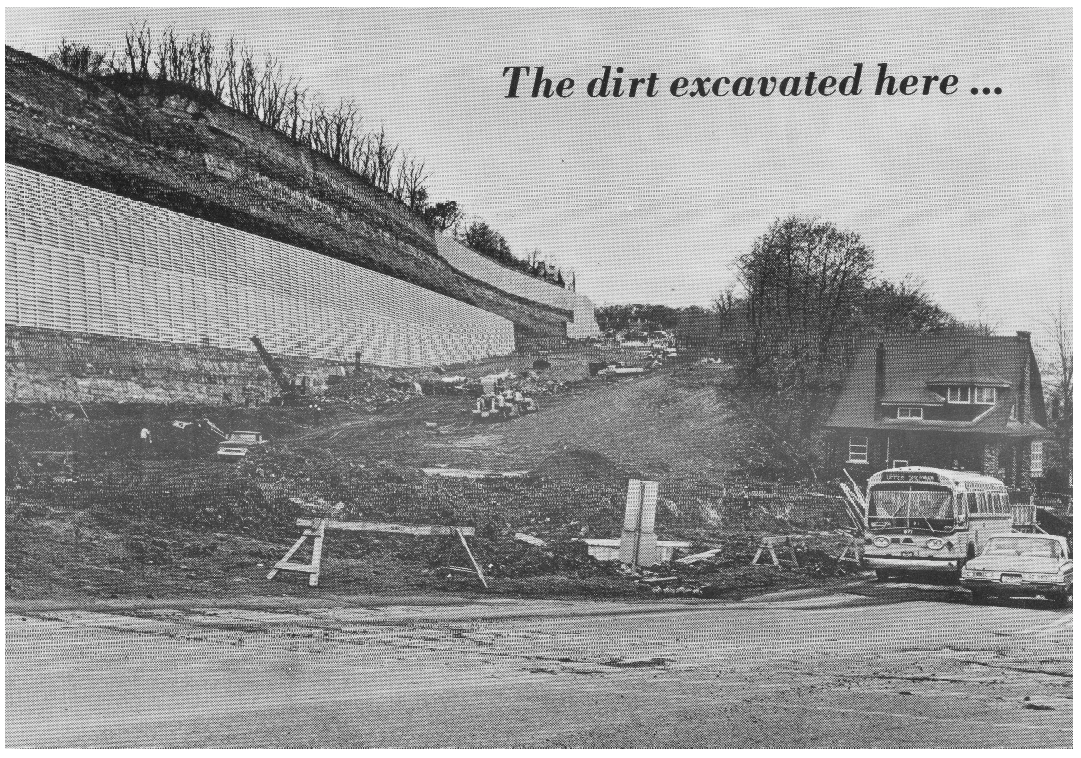

\section{... is dumped in the middle of this bay}

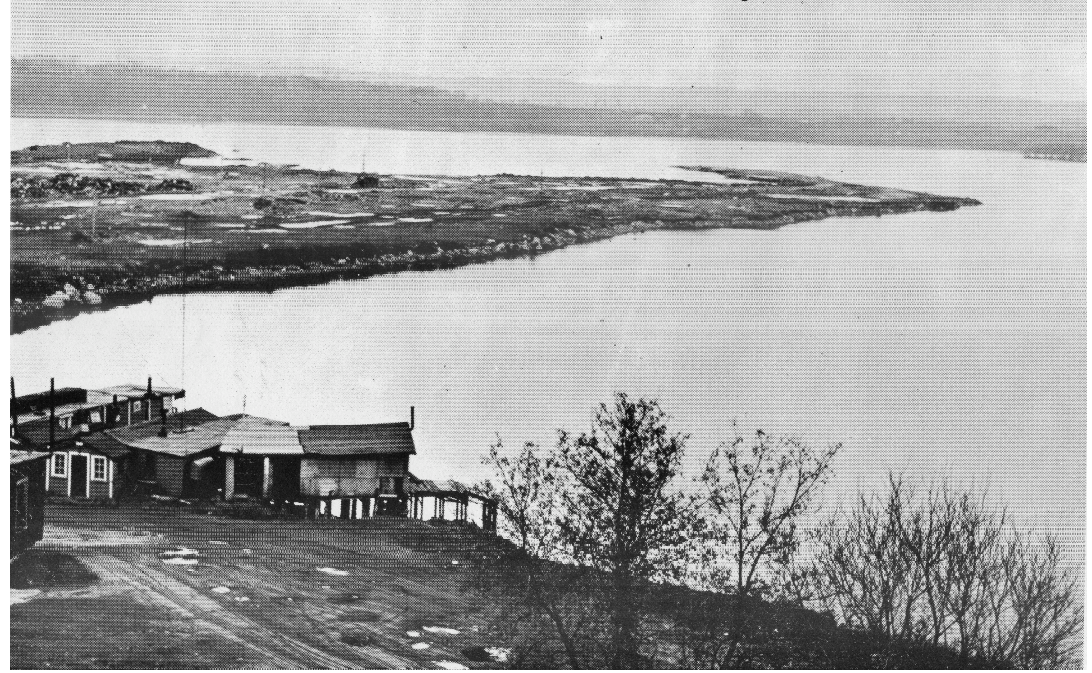

From Ti Estin [McMaster University Silhouette supplement] 28 November 1969, 29. Courtesy of McMaster University Silbouette, photographer unknown. 
acknowledge multiple ways of seeing." ${ }^{15}$ In Figure 5, we see the Lax Lands from an alternative perspective, one that was intended to mobilize resistance to the project. This pair of photographs appeared in a special 1969 supplement of McMaster University's student newspaper, the Silhouette. Student activists revised and republished the supplement, Ti Estin, for wider distribution in June 1970, "to serve as an illustrated handbook through which people can learn the fundamentals of pollution, ecology, and conservation; that is, to help people become reasonably wellinformed on environmental questions."16 Articles such as, "Who will save the Great Lakes?", "Fighting Pollution: No Soap", and "Pollution as a Road to Nowhere", exposed the problem of pollution as student radicals saw it. Photo essays like "The Photogenesis of Filth" captured images of ecological damage and impending disaster in Hamilton's urban landscape. One contributor to Ti Estin recalled: "Instead of seeing the industrial complex on the bay as our bread and butter, we were flipping the coin." ${ }^{17}$

When compared to Figure 3, the image of the Lax Lands in Figure 5 indeed flips the coin. In the activist photograph, we are looking west rather than east, a change that places the Cootes Paradise bird sanctuary and the protected Niagara Escarpment, rather than the industrial urban landscape, on the horizon. The ground-level perspective contrasts with the Harbour Commission's birds-eye (and quite expensive) aerial photography, and brings the boathouses and shoreline shacks into the foreground. The harbour becomes a bay, a place where people obviously live, work, and play. Where would they go if not here? ${ }^{18}$ The accompanying photograph literally grounds the infilling, showing that the dirt did not just appear, it was moved. Members of the community would have recognized that this was a construction site along the escarpment, where green space was giving way to the automobile. The photographs underline the efforts of environmental activists to insist on

Figure 6. Citizens Speak Out: Clear Hamilton of Pollution [CHOP]

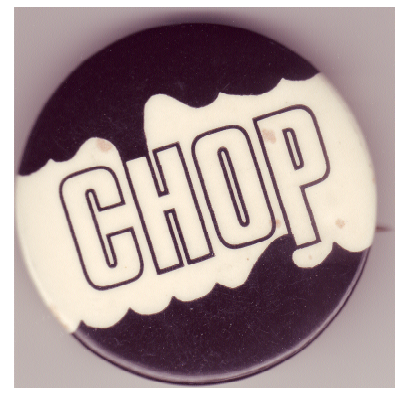

Courtesy of Nancy Bouchier, photographer, 2007. the connections between issues. Student activists declared an Autoban Day-a car-free day-in March 1970, to raise awareness about society's dependence on automobiles and to sensitize people to their impact on the environment. ${ }^{19}$

Many of those student activists would have been participating in Clear Hamilton of Pollution (CHOP). The organization's button (Figure 6) conveys its concerns, with its graphic presentation of a smokestack belching pollutants into the air and a drainpipe dumping effluent into the water. In the spring of 1969, 25 concerned Hamiltonians banded together to form CHOP, a citizen action group, to increase public awareness about pollution, to act as a pressure group for political action, and to sue environmental offenders. ${ }^{20}$ Informed by the work of com- 
munity activist thinkers like Ralph Nader and Saul Alinsky, and linked to similar organizations in Toronto and Guelph, CHOP members aimed to put the environment front and centre in the public eye and turn it into one of the major issues facing all levels of government. ${ }^{21}$ As we know from the work of historians Jennifer Read, Adam Rome, and others, CHOP reflected the new social movements that sprang up around North America around this time, movements that posed serious questions about the meaning of progress. ${ }^{22}$ In cities around North America, activists challenged the use of phosphates and DDT, the construction of urban expressways, and the redevelopment of neighbourhoods in the name of urban renewal, linking those challenges to questions of power. "Environmental groups such as ours", opined CHOP's president in an early newsletter, "have a very important role to play in combating public apathy and promoting the idea that it is 'people' who ultimately determine what is best for them - not some 'big brother' in Hamilton City Hall, Queen's Park, or Parliament Hill." ${ }^{23}$ He drew on the rhetoric surrounding Canada's newly-elected and charismatic Prime Minister, Pierre Elliott Trudeau, to define the organization: "Participatory Democracy, that fine sounding phrase, can only become a reality if our representatives listen to what we have to say. Organizations, such as CHOP, can play a role in articulating the feelings of our fellow citizens." ${ }^{24}$

As Figure 5 illustrates, the Lax Lands became a lightning rod for this environmental and citizen activism. The watchdog group Save Our Bay (SOB), which grew out of a meeting organized by a local community association, quickly allied itself with CHOP and other environmental groups in the city. "Although the Save Our Bay Committee has lined up the Lax island development as its number one target", noted one reporter, "its 'enemy' on the wider scale is the Hamilton Harbour Commission." 26 SOB had many reasons to oppose the Lax development: "some [members] were tired of the noise, some were against the value of their homes being lowered, others were fighting against the destruction of their community." 27 In framing the infilling as a question of environment and democracy, and by attributing the policy of infilling to the unelected harbour commissioners, CHOP and SOB eventually gained the support of the local newspaper editors, the conservation authority and city councillors. As the editor of the Hamilton Spectator put it, "...if the harbor commission can sell off pieces of the bay for land-fill, what's to prevent the whole bay from being filled in, except for a few shipping channels?"28

Whatever political and ideological resources the Harbour Commission had to reassert its vision of harbour development, and they were considerable, evaporated when the RCMP began investigating the agency for kickbacks over dredging contracts. ${ }^{29}$ The agency faced "overwhelming constraints," and although the scandal was not about the Lax firm, their project - as well as others - ground to a halt. ${ }^{30}$ By listening to community members and by conveying their messages through written, oral and visual messages delivered in letter-writing campaigns, 
Figure 7. Cees Van Gemerden: the Lax Lands

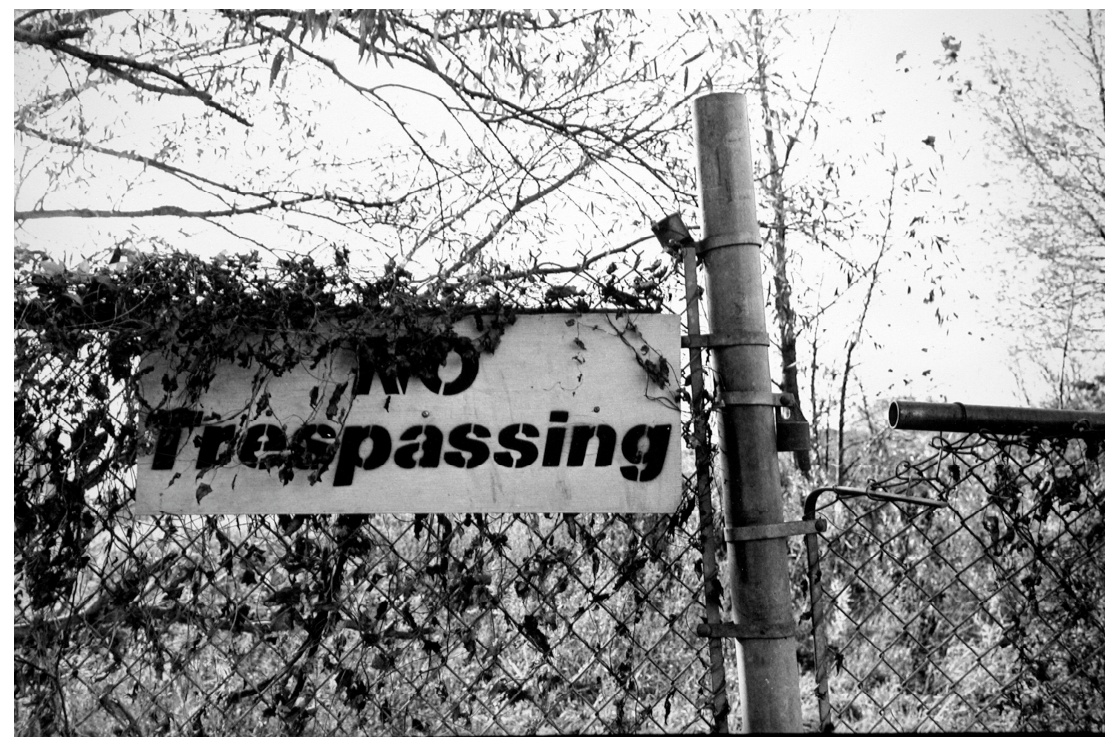

From 'Trespassing - More Power Anyone?' Exhibit (1992). Photograph \#1. Courtesy of Cees Van Gemerden, photographer.

protests, events, community meetings, and public lectures, student and citizen activists effectively brought Hamilton's environmental problem to the attention of a wider public. ${ }^{31}$ And what happened to the Lax Lands? For an answer, we can turn to the photographic vision of a late-twentieth-century artist activist.

\section{An Artist At Work}

No development took place on the Lax Lands for over a dozen years; port and city officials simply abandoned it while they determined its fate. But neither nature nor local residents abandoned this newly created land. Through his photographic exhibits, Hamilton artist and activist Cees Van Gemerden intended to show that this blighted area on Hamilton's waterfront had a vibrant life of its own. ${ }^{32}$ We have selected four images from his Trespassing-More Power Anyone? (1992) photographic exhibit. ${ }^{33}$ As with his earlier successful, No Trespassing (1989-90) exhibit (which traces the line of fencing that kept people from the bay's southern shore), this work contains a compelling critique from the left, bringing environmental issues to a wider public. ${ }^{34}$ As with all of the other photographers, Van Gemerden consciously framed his shots to convey his vision of the environment, but he also provides us with one of our few records of the area during a time of neglect by official authorities. His camera presents and reveals a hidden world at the Lax Lands, in his words: "a lush diverse landscape, a quiet wild place, a trail created by the 
Figure 8. Clean Fill?

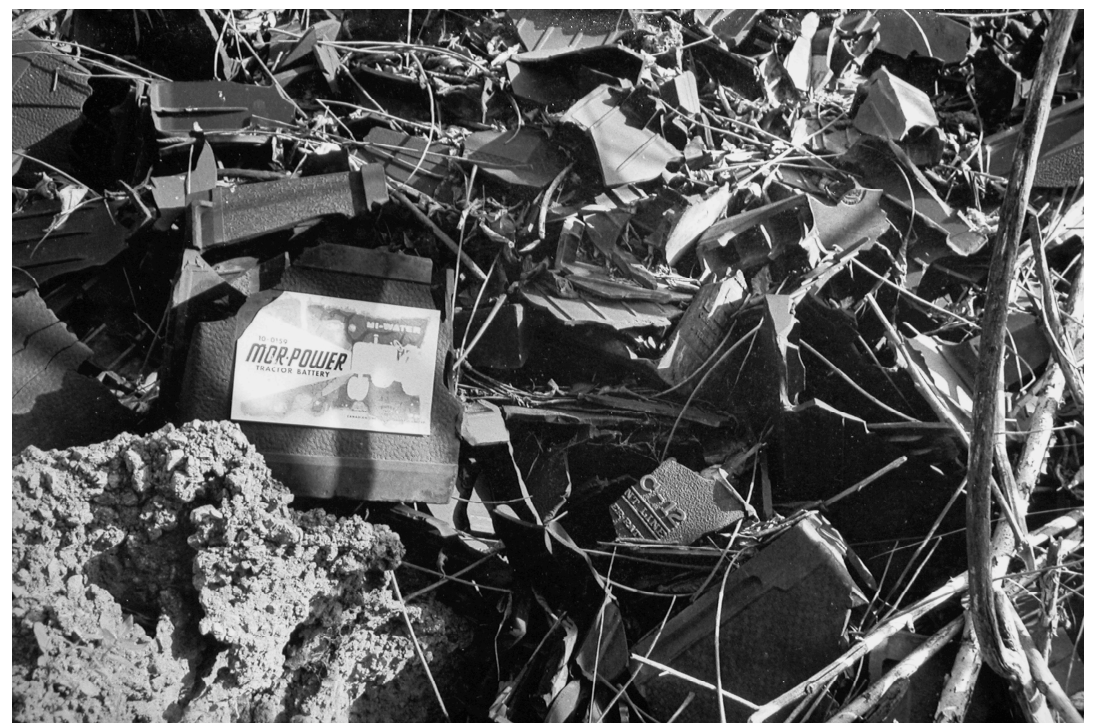

From 'Trespassing - More Power Anyone?' Exhibit (1992). Photograph \#27. Courtesy of Cees Van Gemerden, photographer.

\section{Figure 9. Nature and Regeneration}

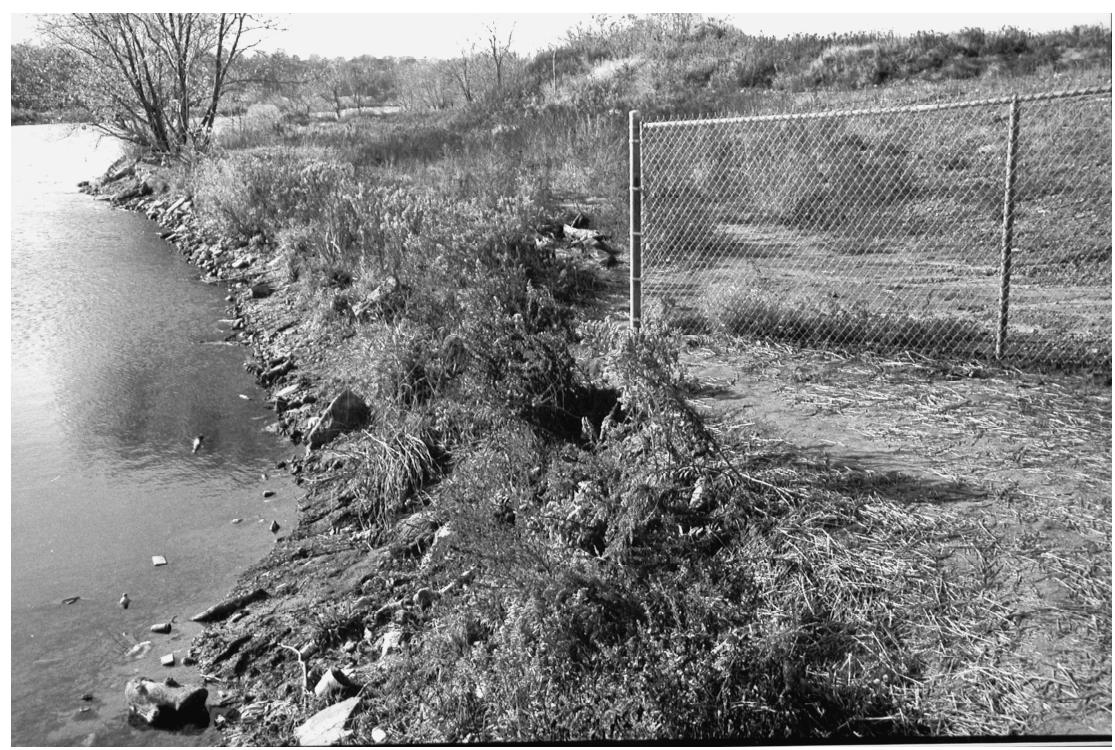

From 'Trespassing - More Power Anyone?' Exhibit (1992). Photograph \# 2. Courtesy of Cees Van Gemerden, photographer. 
Figure 10. Nature and Transgression

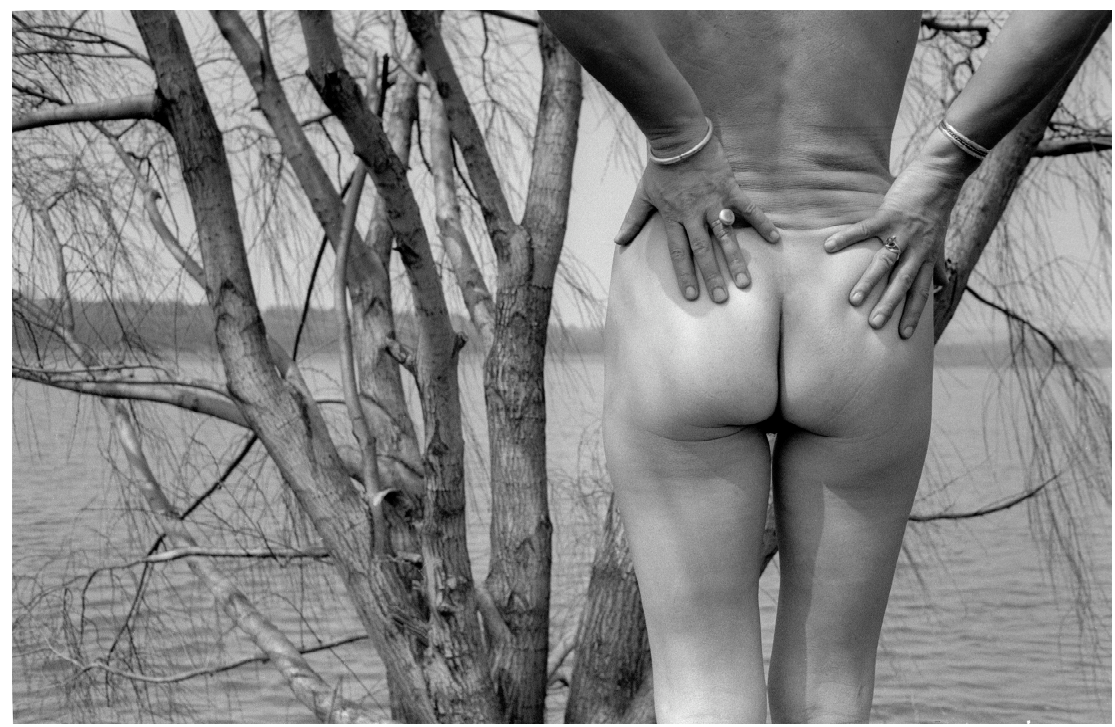

Courtesy of Cees Van Gemerden, photographer, 1985.

footsteps of curious children, lovers, young people looking for a private place and solitary, homeless people in search of a place to sleep." ${ }^{35}$

Despite one report in the Spectator that "there was no vegetation growing on the site", the photographs show abundant life, including a diverse array of trees, plants, and shrubs springing up from the ground, unassisted by human hands. ${ }^{36}$ Vegetation is featured in all of these photographs, even growing over the "No Trespassing" signs in Figure 7 and amid the discarded battery cases in Figure 8. The batteries, the paths beyond the fence in Figure 9, and the woman enjoying a quiet moment of solitude in Figure 10, all suggest that the signs made little difference to people either. Van Gemerden first took some of these photographs at a time when the future of this place was still open, and asserted its significance as a public green space, even in its abandoned condition. Nowhere is this clearer than in Figure 10. As Margarite Shaffer recently suggested, nudity emerged in the 1960 s "as a kind of personalized political performance," which, among other objectives, "offered a critique of modern alienated modern culture." ${ }_{37}$ The photograph celebrates the beauty of nature and the cycles of life along the waterfront. A strong and healthy woman stands tall and gazes out thoughtfully and defiantly at the water. It is a season of change. She is not young, but she is also not old. Her stance suggests that life still holds much potential. Empty tree branches blow in the offshore breeze. The water ripples with the wind. Change is surely coming, but for now all is well with the world.

Change was indeed coming, and Van Gemerden was anxious not to let 
his viewers forget the history of this place. While the discarded batteries in Figure 8 could have been dumped at any time, they help convey in visual form what the artist and the rest of the city knew about this place by the 1980s. The earth that had been used to create this place was not clean fill, but highly toxic. In 1984, after over a decade of debate and negotiation, Hamilton's city council finally expropriated the acres of land filled in by the Lax Brothers. Following an idea forwarded by SOB many years earlier, it decided to build a public waterfront recreational park on the land. ${ }^{38}$ Before its construction could begin, some 20000 tonnes of industrial waste and contaminated soil had to be first removed since the soil was found to contain high levels of lead, cadmium, and other chemical toxins. ${ }^{39}$ According to Ministry of Environment regulations, each truckload of toxic fill removed from the Lax site had to be covered with a tarp to prevent materials from spilling, and the tires of the truck had first to be hosed down before it was to leave the area.

\section{Restorationists at Work}

Restoration work almost inevitably erases certain features of a blighted area's past. When activists win battles and things change for the better, it is all too easy for future generations to take the changes for granted and to forget the battles once fought. Hamilton's Bayfront Park is a case in point. It finally opened in 1993, as a very consciously-crafted parkland, perhaps artificial in origin, but designed to be a natural waterfront space. Planners worked to leave no traces of the park's past as a landfill dump. After the industrial waste and contaminated soil had been removed from the site, they capped the area with clay, brought in 'clean' topsoil, and used native plants for landscaping. Working with Remedial Action Plan (RAP) biologists and in consultation with community groups like the Conserver Society and the Bay Area Restoration Council, as well as with stakeholders from industries like Stelco and Dofasco, park planners designed a fish, bird, and people-friendly shoreline. $^{40}$

Figure 11 provides one perspective of their work, a photograph taken for the Hamilton Port Authority, successor to the Harbour Commission. Central to this panoramic shot is the transformed Lax lands, the large, open and green park that dominates this picture. Readers of this photographic essay will recognize the original contours of the infilled promontory from the 1973 photograph. Still relying on aerial photography, the Port Authority captures the entire harbour in this shot. Industry and transportation are well represented - the railway yards remain and a Great Lakes ship is clearly visible in the harbour; the steel mills are somewhat harder to make out in the distance, and are less distinct than the homes of the city. The photograph captures the contemporary Port Authority vision of balance, with public waterfront parks and residential neighbourhoods coexisting with commercial and industrial use.

Figures 12-13 celebrate the expanding waterfront park as a public recre- 
Figure 11. Bayfront Park and the West Harbour, 1995.

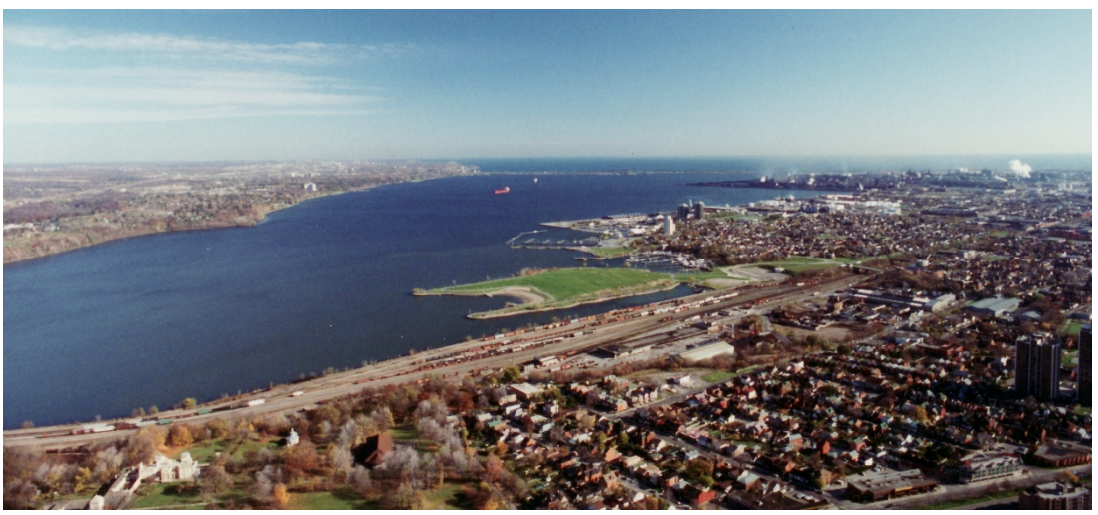

Figure 12. The Waterfront Trail

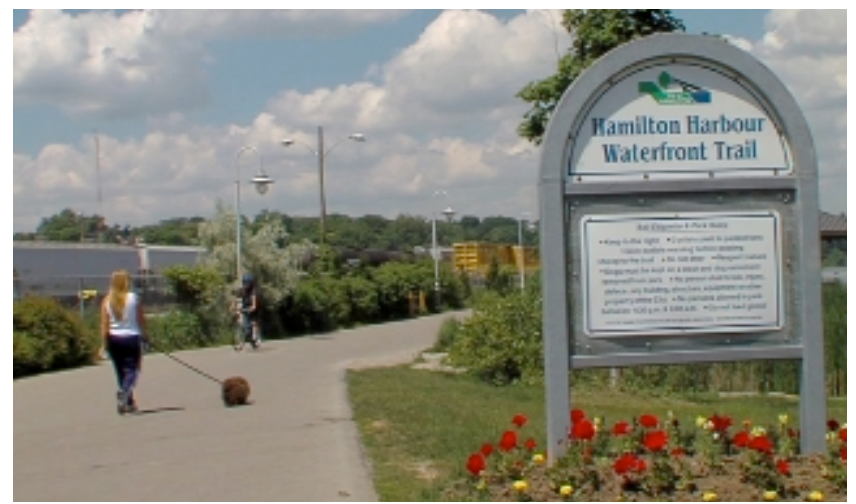

Figure 13. A Place for Birds, Fish, and People

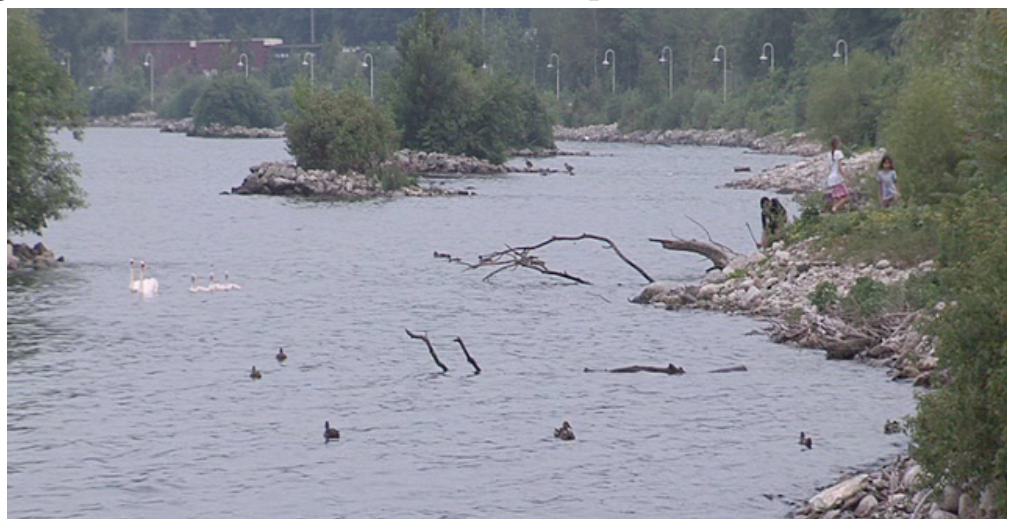

Figure 11 Courtesy of Hamilton Port Authority, Photographer unknown, 1995. Figures 12 and 13 from The People and the Bay (film), 2007. Director and Photographer, Zack Melnick, Pixel Dust Studios. Courtesy of the L.R. Wilson Centre for Canadian History, McMaster University. 
ational space, and as a site of environmental restoration. The photographs emphasize people and recreation along the shoreline. Figure 12 highlights Hamilton's Waterfront Trail. This carefully and consciously crafted area aims to be in tune with natural processes, with its shoreline designed by biologists to encourage the growth of self-sustaining fish and wildlife, and with native plants not just pretty flowers-lining its way. The trail aims to get Hamiltonians in touch with nature, and to provide them with both visual and physical aesthetic experiences. It gives pedestrians, cyclists, and people in wheelchairs, on scooters, and on inline skates an opportunity to travel along the water's edge from Bayfront Park to the nature sanctuary at Cootes Paradise in the Royal Botanical Gardens. ${ }^{41}$ Similarly, Figure 13 depicts recreation and successful natural restoration of the shoreline: swans and their goslings and ducks paddle near children exploring the shore. The environmental planners aimed to accommodate a wide variety of social and recreational activities, seeing the educative value of these new natural spaces. ${ }^{42}$ They hope that those who use the park and trails will become more aware of and concerned about their natural environment. These two images come from the final moments of a documentary, The People and the Bay, that we recently scripted and narrated. Like the Harbour Commission photograph, it ends on an upbeat note, praising the attempts to balance natural processes, public recreational access and industrial development. ${ }^{43}$

\section{Historical Memory at Work}

We hope that the images in our documentary will be understood in context, that we have managed to use other historical images to connect people from this pres-

\section{Figure 14. No Trespassing Exhibit at Hamilton's Aquafest}

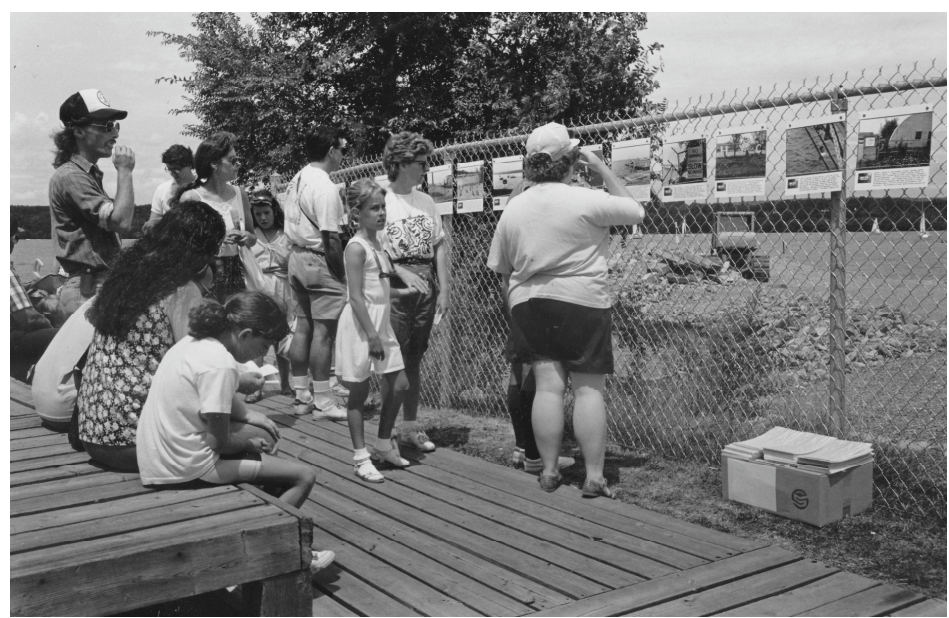

Courtesy of Cees Van Gemerden, photographer, 1996. 


\section{Figure 15. Reality Check: Swimming at Bayfront Park Beach}

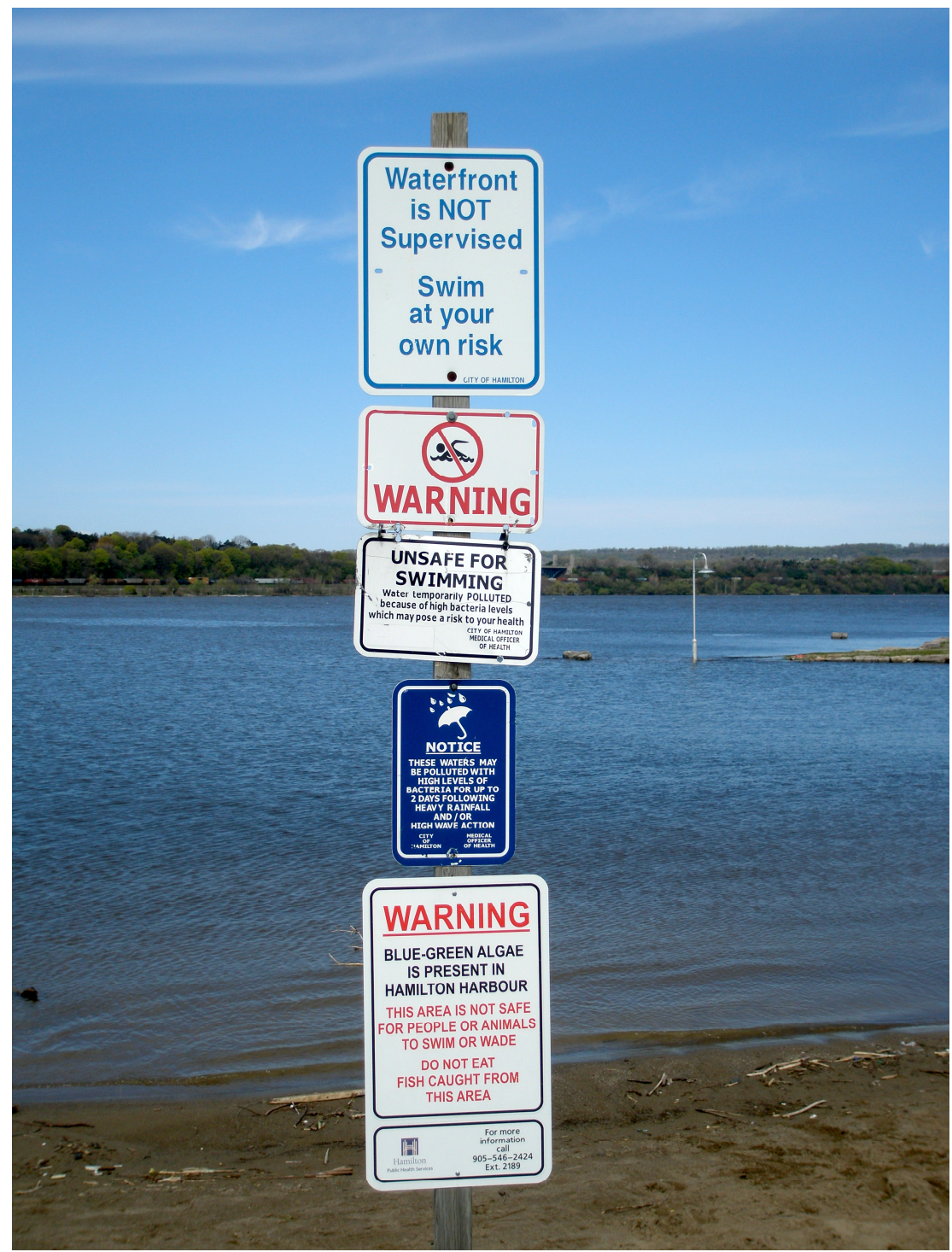

Courtesy of Nancy Bouchier, photographer.

ent they value to a past they do not, and to make them realize that these changes did not just happen-people made them happen. And yet we worry. How will the struggle for the environment be memorialized? And, by whom? In Hamilton, articles in the local press with titles, like "Waterfront park a tribute to those who 
Figure 16. An Environmental Heritage Plaque Anyone?

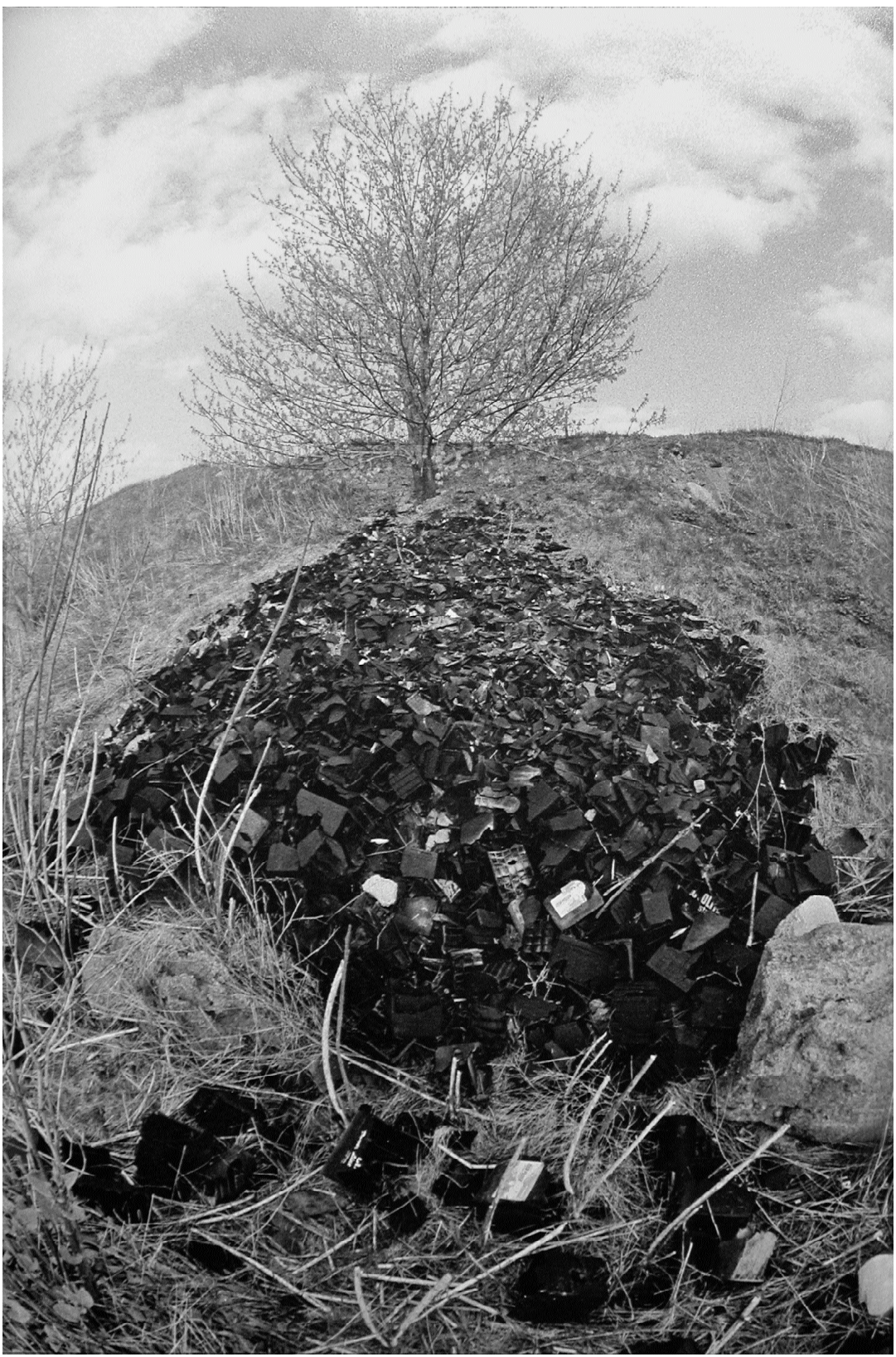

From 'The Maple Tree versus Battery Cases.' Trespassing - More Power Anyone? Exhibit (1992). Photograph \#28. Courtesy of Cees Van Gemerden, photographer. 
dared to follow a vision", suggest that there is some awareness of the struggle made and the victories won in the case of the bay. ${ }^{44}$ On the other hand, Hamilton's public works website erases historical actors from the process of creating Bayfront Park, claiming: "What began as a project to remediate a large industrial landfill site resulted in the transformation of this site into a versatile public green space." ${ }^{45}$

Figure 14 depicts one of Cees Van Gemerden's contributions to sustaining historical memory, through an exhibition of his photographs at one of several waterfront festivals organized to draw the public to the waterfront. Curious people at Aquafest stop to examine the 78 photograph and text panels of his 1990 No Trespassing exhibit-a damning critique of the lack of public access to the Hamilton Harbour shoreline, and an effort to remind people of the struggle for the bay. The exhibit was all too temporary. More permanent images can be found on historical plaques lining the city's new Waterfront Trail. They highlight various aspects of the harbour's history - the city's early railway yards, the ice-cutting industry, the flora planted and fauna encouraged to repopulate in the area, the volunteer work of community members, and the Bay Area Restoration Council planting native trees and plants along the bay's shore. ${ }^{46}$ They do not, however, memorialize the struggles of local activists in "the battle to unchain Hamilton Bay" from development, or even their efforts to get access for ordinary citizens along the water's edge.

And we worry that images like those at the end of our documentary could leave viewers complacent about the present. We wish that we had included images like Figure 15 at its close. For as lovely as the Bayfront Park is as depicted in these photographs, there are concerns. Those children on the shoreline still need to stay out of the water. Swimming is not at all advisable for any living thing, apparently not even fish. Warnings about pollution, blue-green algae, and the lack of supervision deter people from getting into the water. They are instructed to keep animals from swimming or wading in the water. "Do not eat the fish", they are told. We need images that convey the message: there is work to be done.

We conclude this photographic essay with one last image. Too bad that the scene captured by Cees van Gemerden's "The Maple Tree versus Battery Cases" could not have been preserved in Bayfront Park as a historical site, as he had once hoped. It would have stood as testimony to the fragility and resilience of nature, to the damage and neglect of industrial society, to the work that has been done, and the work that still needs to be done. Too bad it is just a photograph.

\section{NOTES}

The authors wish to thank the anonymous reviewers for their helpful suggestions for revisions to the paper and the Social Sciences and Humanities Research Council of Canada for their financial support of this research. We are grateful to the Hamilton Port Authority, the L.R. Wilson Centre for Canadian History, and especially Cees Van Gemerden, for their willingness to share their photographs with us. 
1 Joan M. Schwartz, "Photographic Reflections: Nature, Landscape and Environment," Environmental History 12, no. 4 (2007): 990.

2 John Tagg, The Burden of Representation: Essay on Photographies and Histories (Minneapolis: University of Minnesota Press, 1993), 117.

3 Schwartz, 968, 991. For an interesting photographic essay that is sensitive to these critiques of historians, see James Murton, "What J.W. Clark Saw in British Columbia, or Nature and the Machine: A Photo Essay,” BC Studies142/143 (2003): 129-152. For a helpful introduction to approaches to visual culture, see Gillian Rose, Visual Methodologies (London: Sage, 2001).

4 Mitchell Smyth, "The Battle to Unchain Hamilton Bay," Hamilton Spectator, 25 August 1971.

5 For an overview, see Ken Cruikshank and Nancy B. Bouchier, "Blighted Areas and Obnoxious Industries: Constructing Envi ronmental Inequality on an Industrial Waterfront, Hamilton, Ontario, 1890-1960," Environmental History 9 (July 2004): 464496.

6 A private member's bill in 1912 created a commission for Hamilton similar to the one created for Toronto in the previous year. See: "Hamilton May Have a Harbor Commission," Hamilton Spectator, 22 April 1911, 1; "Hamilton Will Have a Harbor Commission," Hamilton Spectator, 2 February 1912. For an overview, see: Mark Sproule-Jones, Governments at Work (Toronto: University of Toronto Press, 1993), 135-142.

7 For example, the use of cobblestones to increase waterfront land as they were replaced with asphalt roads in Toronto. On Toronto's harbour, see: Roy Merrens, "Port Authorities as Urban Land Developers: The Case of the Toronto Harbour Commissioners and Their Outer Harbour Project, 1912-1968," Urban History Review 17, no. 2 (October 1988): 92-105; Gene Desfor, "Planning Urban Waterfront Industrial Districts: Toronto's Ashbridge's Bay, 1889-1910," Urban History Review 17, no. 2 (October 1988): 77-90; Matthew Cooper, "Access to the Waterfront: Transformations of Meaning on the Toronto Lakeshore," in The Cultural Meaning of Urban Space, eds. Gary McDonogh and R.L. Rotenberg (Westport, CT: Bergin and Garvey, 1993), 157-171.

8 See, for example, Hamilton Port Authority Photographs: 1956 Beach Removals (Photographer unknown); 1957 Infilling East Harbour (Photographer unknown); 1957 Pier 14 (Photographer unknown); 1959 Stelco 3601-7 (Photographer Phil Aggus); 1972 Pier 12 5331-5 (Photographer Phil Aggus and Son).

9 See, Robert J. Hanley and Frank Oxley, "Port of Hamilton," Hamilton Spectator, 27, 28, 29 May 1957; Hamilton Harbour Commission Annual Report, 1958; On the opening of the Seaway, see: "Finally, the St. Lawrence Seaway is completed". (CBC Television Broadcast April 26, 1959). CBC Archives. http://archives.cbc.ca/science_technology/transportation/topics/637 (accessed 22 June 2008).

10 Underneath the Skyway, on the bay side of the beach strip - which was once a popular holiday spot for the region - a nuclear power generating plant had also been proposed. See, "Nuclear Power Work Here Seen Assisting All Ontario," Hamilton Spectator, 28 December 1955; "Will Generate Power on Harbor Site," Hamilton Spectator, 23 August 1957.

11 For an overview, see: Bill Freeman and Marsha Hewitt, "Hamilton Harbour: Politics, 
patronage, and cover-up". in Their Town: The Mafia, the Media, and the Party Machine, eds. Freeman and Hewitt (Toronto: J. Lorimer, 1979), 149.

12 "Save Our Bay," Community Forum, June 1971. This article names the development project 'Bal Harbour,' while later descriptions refer to 'Bayshore Village.' The Bal Harbour development idea appears to have preceded the Bayshore Village idea. It aimed to create an island development for residential and park use. See: Letter to the editor by Fred. J. Losee, A.I.P. "Hamilton Bay's great potentiality," Hamilton Spectator, 14 August 1971. Losee argued that this was a tremendous development opportunity for the city which ought not to be missed, and he questioned the merits of developing the area as mere park land. On the switch from developing the Lax site from industrial to residential, the nebulous fate of the perimeter road plans, which would connect the industrial east end to a new highway to Toronto, appears to have been a factor. On anticipated transport plans see, Hamilton Harbour Commission Annual Report, 1958.

13 For a sample of the debate, see "Complex Battle Raging Over 120 Acres of Landfill," Hamilton Spectator, 18 October 1969; "Bay Fill-In Beyond OWRC's Powers," Hamilton Spectator, 9 July 1971; "HHC Controls Bay Fill-In," Hamilton Spectator, 10 July 1971; "Conservation Body Seeking Control Over Landfill in Bay," Hamilton Spectator, 8 October 1972; "Save Our Bay Group Backs City," Hamilton Spectator, 25 January 1972; "Planners Oppose Bay Fill," Hamilton Spectator, 23 January 1972; Rudy Platiel, “Hamilton Bay's 56-acre eyesore," Hamilton Spectator, 17 May 1974.

14 Memo to Minister re: Financial Assistance to Hamilton Harbour Commission, 2 December 1977, Interdepartmental Group on Harbours - Hamilton Harbour Commission, File 8103-50-4 part 1, Box 15, RG12, Department of Transport, Library and Archives Canada.

15 Annette Kuhn and Kirsten Emiko McAllister, "Locating Memory: Photographic Acts - An Introduction" in Locating Memory: Photographic Acts, eds. Kuhn and McAllister (New York: Berghahn Books, 2006), 4.

16 Ti Estin, 28 November 1969, 2. So-named after the Socratic notion of 'essence', this edition was revised and republished for wider distribution in June 1970. McMaster students, who had their own Ontario Public Interest Research Group (OPIRG) chapter, had good connections to the University of Toronto's Pollution Probe group. See, for example, Clear Hamilton of Pollution (CHOP) Papers, Minutes, 9 December 1969; 19 February 1970; 10 March 1970.

17 Interview, 22 March 2007.

18 For an analysis of the social implications of the city's efforts to clear the shoreline in another part of the bay, see, Nancy B. Bouchier and Ken Cruikshank, "The War on the Squatters, 1920-1940: Hamilton's Boathouse Community and the Re-Creation of Recreation on Burlington Bay," Labour/Le Travail 51 (Spring, 2003): 9-46.

19 CHOP Papers. Auto Ban Flyer, 5 March 1970; Interview, 22 March 2007.

20 CHOP Newsletter, 1970; CHOP History, March 1970; Letters Patent Incorporating Clear Hamilton of Pollution, 15 October 1973. At its outset CHOP identified its first priority as 'air pollution;' Within a year of its creation, CHOP members helped create a council of anti-pollution organizations in Hamilton, made up of twelve member organizations. (CHOP First Annual Report, March 1971). It became the Federation of Anti-Pollution Groups, which worked in liaison with the City's newly-formed Pollution 
Committee (Minutes, 17 May 1971); Today CHOP is the Conserver Society, whose mission is: "Promoting solutions for a sustainable environment through education, community action, advocacy and collaboration." Since 1990 it has had local chapters in Burlington, Ancaster, Flamborough, Hamilton, and Dundas. See: http://www.conserversociety.ca/ (accessed 22 August 2008)

21 CHOP Papers. "Statements by Saul Alinksy - 19 November 1971. The A.B.C.s of Social Action”. See also, Saul Alinksy, Rules for Radicals: A Pragmatic Primer for Realistic Radicals (New York: Random House, 1971).

22 Jennifer Read, “'Let us heed the voice of youth': Laundry Detergents, Phosphates and the Emergence of the Environmental Movement in Ontario," Journal of the Canadian Historical Association 9 (1996): 227-250; Adam Rome, "'Give Earth a Chance': The Environmental Movement and the Sixties," Journal of American History 90, no. 2 (September 2003): 525-554; See also, Robert Gottlieb, Forcing the Spring: The Transformation of the American Environmental Movement (Washington: Island Press, 1993).

23 CHOP Newsletter \#4, June 1972.

24 Ibid; In 1974 two summer students wrote a paper for the organization, critically assessing CHOP's role in the broader scheme of things. Lamenting the culture of specialization, they posed the question, "Must we be forced to allow a few select individuals to make all significant social decisions when in fact such decisions involve ethics and morals much more than technology and science? It is an unjust and perilous situation when the average citizen is not allowed to be involved in the decision-making process." CHOP, they argued, gave the average citizen opportunities to express their opinion and to be heard. See, CHOP Papers. Ann Gordon and Marg Wingfield, "A Critical Assessment of CHOP's Organization," 8 October 1974, 1.

25 "Save Our Bay"; See also: (by G.S.) "The Things We Did Last Summer," Hamilton Spectator, 18 September 1971; CHOP Minutes, 28 June 1971. The Association, incorporated in 1974 as the Victoria Park Community Homes, is today one of the oldest and largest private non-profit housing corporations in the province of Ontario. Its mission statement declares it, "a dedicated team of board and staff committed to strengthening individuals, families, neighbourhoods and communities by providing stable, quality affordable homes." http://www.vpch.com/ (accessed 22 August 2008).

26 Mitchell Smyth, "Save our Bay aims at harbor group," Hamilton Spectator, 25 August 1971.

27 CHOP Papers. David Roe, "Bay + Garbage = Gold ... for some," 1971.

28 Editor, "Kerr on the Waterfront," Hamilton Spectator, 12 August 1971.

29 See Hamilton Public Library, Local History and Archives Hamilton Harbour Case Scrapbook, vol. 1 \& 2, R345.710232.E158 Cana H.

30 "Hamilton Harbour: Politics, patronage, and cover-up".

31 For a sample of the debate, see CHOP Minutes, 9 December 1969; "Complex Battle Raging Over 120 Acres of Landfill," Hamilton Spectator, 18 October 1969; "Bay Fill-In Beyond OWRC's Powers," Hamilton Spectator, 9 July 1971; "HHC Controls Bay Fill-In," Hamilton Spectator, 10 July 1971; "Conservation Body Seeking Control Over Landfill in Bay," Hamilton Spectator, 8 October 1972; "Save Our Bay Group Backs City," Hamilton Spectator, 25 January 1972; "Planners Oppose Bay Fill," 23 January 1972; Rudy Platiel, "Hamilton Bay's 56-acre eyesore," Hamilton Spectator, 17 May 1974.

32 A long-time member of the New Democratic Party (NDP) who recently has become 
interested in Green Party politics, Van Gemerden is a noted Hamilton artist and activist living for the past 25 years in Hamilton's North End neighbourhood. He is a member of Hamilton Artists Inc., and most recently has been involved with the community group, Friends of the Red Hill Valley, using his photographs in the fight against Hamilton's Red Hill Expressway. See, for example, “Tree Sitters Re-supplied.” Citizens at City Hall (CATCH) website (13 June 2004), http:/ / www.hamiltoncatch.org/archives /articles/art_0406/art_040613treesitters.htm (accessed 21 August 2008).

33 Cees Van Gemerden, Trespassing More Power Anyone? (Bay Area) Photographers Show. Burlington Cultural Centre (24 May-26 July 1992). This exhibit has been re-shown a number of times, most recently at the you me gallery 11 May-23 June 2007, 330 James St. N. Hamilton.

34 See, Cees Van Gemerden, No Trespassing. The Photography Gallery Toronto Harbourfront (15 December-28 January 1990). The exhibit comprised some 78 photographs along Hamilton's waterfront. Lines of text from environmental news stories from around the world, local news on Hamilton's harbour, and personal notes by the artist accompanied each photograph in the exhibit. One of the photographs from the exhibit is reproduced in Alexander Wilson's introduction to his The Culture of Nature: North American Landscape from Disney to Exxon Valdez (Toronto: University of Toronto Press, 1991), 6; On other activist work by the artist and other activists in Hamilton's arts community, see Elane Hujer, "Artist's Red Hill photo elicits passionate response," Hamilton Spectator, 3 March 2004, G11; Letter to the Editor, "Mayor doesn't speak for me," Hamilton Spectator, May 10, 2002, A14; Jeff Mahoney, "The art of serving others; Can I Help You? deals frankly with a group of workers we take for granted," Hamilton Spectator, January 18, 2001, B03; Jeff Mahoney, "Focussing on the Big Picture," Hamilton Spectator, October 5, 2000, D14; Anne Marie Todkill, "Reading the Times,". Canadian Medical Association Journal 161, no. 10 (16 November 1999): 1299-1300.

35 Gemerden, “Artist's Statement," Trespassing More Power Anyone?

36 Emilla Casella, "Province comes up with Lax land cash," Hamilton Spectator, 11 October 1991, A1.

37 Marguerite S. Shaffer, “On the Environmental Nude," Environmental History 13, no. 1 (2008): 135, 137.

38 The Conserver Society (formerly CHOP) was involved in the waterfront planning sessions and the Environmental Assessment process see, Chairman's Report to the Membership for 1985, 18 March 1986; Letter from Edgar E. Smee to Ministry of the Environment, Environmental Assessment Advisory Committee, 24 March 1987; See also, Rita Devgan and David Stickney, Focus on the bay: concepts and design approaches for Hamilton harbour. (Hamilton: Hamilton Harbour Advisory Committee, 1983).

39 Canviro Consultants and Bar Environmental prepared for City of Hamilton. Remediation Plan for the Former Lax Property (17 March 1989), 1.

40 See, G.K.R. Rodgers, J. Vogt, D. Boyd, L. Simser, H. Lang, T. Murphy and D.S. Painter, Remedial Action Plan for Hamilton Harbour: Goals, Options and Recommendations (1992); Government of Ontario, Ministry of the Environment. Hamilton Harbour Remedial Action Plan (1993); City of Hamilton, Waterfront parks: Pier 4 and Bayfront Park. (Hamilton, 1997); Bay Area Restoration Council (of Hamilton-Wentworth and Halton Regions, Inc), Bringing Back the Bay (January 2001); John D. Hall, Kristin O’Connor, and Joanna Ranieri,"Progress Toward Delisting A Great Lakes Area of Concern: The Role of 
Integrated Research and Monitoring in the Hamilton Harbour Remedial Action Plan," Environmental Monitoring and Assessment 113 (2006): 227-243; for RAP progress and reports generally, see: http://www.hamiltonharbour.ca/rap/reports.htm (accessed 22 August 2008).

41 Russ Doyle, "Waterfront Trail is worth bragging about," Hamilton Spectator, 4 August 2000.

42 On the recreation profession and environmentalism, see E.L. Jackson, "Outdoor recreation participation and attitudes to the environment," Leisure Studies (1986): 2-9.

43 The People and the Bay: The Story of Hamilton Harbour, documentary film, directed by Zach Melnick and produced by Yvonne Drebert (2007; Pixel Dust Studios, York ON). L.R. Wilson Centre for Canadian History, McMaster University. The documentary was shot in the spring and summer of 2006 and produced for McMaster University's L.R. Wilson Centre for Canadian History as part of its outreach to area schools. On the documentary, see, Wade Hemsworth, "Harbour Heritage Documented for posterity: How we used it and abused it," Hamilton Spectator, 19 October 2007.

44 Tami Paikin Nolan, "Waterfront park a tribute to those who dared to follow a vision," Hamilton Spectator, 11 August 1993, B1.

45 http://www.myhamilton.ca/myhamilton/CityandGovernment/CityDepartments/ PublicWorks/Parks/Amenities/WaterfrontSprayPads.htm\#wsp (accessed 22 August 2008).

46 See, for example plaques: "The Great Western Railway"; "Hamilton's Harbour Playground"; "Flora and Fauna of Hamilton Harbour"; "Bringing Back the Bay". 